\title{
Flipped Learning to improve students' motivation in Physical Education
}

\author{
Ángela G. Botella ${ }^{1}$, Salvador García-Martínez ${ }^{1}$, Nuria M. García ${ }^{1}$, Javier Olaya-Cuartero ${ }^{2 凶}$, and Alberto Ferriz-Valero ${ }^{1}$ \\ ${ }^{1}$ Department of General and Specific Didactics, Research Group in Physical Education, Fitness and Performance, University of Ali- \\ cante, San Vicente del Raseig, Spain; and ${ }^{2}$ Faculty of Health Sciences, Isabel I University, Burgos, Spain
}

\section{Abstract}

Background: Active methodologies have emerged in which they focus their importance of the teaching-learning process in students and not only on the result. In this way, research has been conducted using the active methodology Flipped Learning (FL) in all areas of Primary, Secondary and Higher Education. Objective: The current study aims to analyze the effect on student motivation after an intervention with the FL teaching technique, using a Parkour Didactic Unit in primary school students. Methods: One hundred students of $6^{\text {th }}$ grade of Primary (11-12 years old) participated in this study, of which, 45 were girls and 55 were boys. It was randomly decided that $6 \circ \mathrm{B}$ and $6 \mathrm{OD}$ would follow the teaching styles that were already used in the center regularly (TRAD group) and otherwise, the $6 \circ \mathrm{A}$ and $6 \circ \mathrm{C}$ groups used FL teaching technique by watching videos created by the principal investigator for the present investigation (FLIP group). The Motivation Questionnaire in Physical Education in primary education and personal interview were applied before and after intervention. Results: The results showed an increase of intrinsic motivation $(p<.001)$, identified motivation $(p<.001)$ and introjected motivation $(p<.001)$ in FLIP group. Moreover, external motivation, as well as the amotivation of the students, has decreased after the intervention. Regarding the TRAD group, a significant decrease in intrinsic motivation and identified motivation was observed. According to qualitative results, the most remarkable thing is that students consider FL as more fun, efficient, accepted and motivating. Conclusions: Intrinsic motivation increased significantly and amotivation values decrease in FL group. FL approach allows using more time in Physical Education classes and, consequently, it is perceived as more fun for the students.

Keywords: flipped classroom, methodology, parkour, Edpuzzle, ICTs

\section{Introduction}

Technology use interrupts the daily activities of children which can result in decreased physical activity (Alotaibi et al., 2020). The little physical activity that many of these children do is centralized in the school, particularly in the area of Physical Education (PE). Even though PE is normally a motivating and fun subject, for these children with sedentary habits, they feel it as an obligation, emerging a feeling of amotivation, considering the subject even frustrating (Gutiérrez et al., 2011; Ntoumanis, 2001; Portman, 1995; Smith \& Parr, 2007).

For this reason, "Highly motivated students show aspects such as a taste for the proposed activities or the desire to waste more time to PE in the school setting" (Castro et al., 2006, p. 9). Motivation in students is an essential aspect in their teaching-learning process since it can change their involvement in classes, improve their attitude and with it, their involvement and effort in carrying out physical activities (Ryan \& Deci, 2000). According to Sanmartín (2014), encouraging students to have a feeling of competence and feel motivated can cause them to make more effort in carrying activities. Self-determination theory is usually used as a macro-theory to understand the function of motivation within the educational background (Ryan \& Deci, 2017, 2020). In fact, this theoretical framework has been successfully used in various studies in Flipped Learning contexts within PE (Campos-Gutiérrez et al., 2021; Fernández-Río et al., 2020; Ferriz-Valero et al., 2017; Gómez-García et al., 2019). Essentially, this theory recognizes three types of regulatory motivations for human behaviour: intrinsic motivation, based on the performance of a behaviour or activity for its inherent satisfaction; extrinsic motivation, referring to the performance of the activity by external recognition or as a means to achieve something; amotivation, that is, the absence of motivation towards the activity (Ryan \& Deci, 2017). From highest to lowest, self-determination, intrinsic motivation, extrinsic motivation and amotivation are located on a continuum (Ryan \& Deci, 2020). Other researchers such as Giménez et al. (2013) affirm that establishing a favorable environment in PE classes that allows students to develop their skills, regardless of their physical capacity, and that they are the protagonist of their own learning process will entail that they feel motivated.

$\triangle$ Corresponding author: Javier Olaya-Cuartero, e-mail javier.olaya@ui1.es, ORCID ${ }^{\circledR}$ record https://orcid.org/0000-0003-1807-7914

Article history: Received January 27 2021, Accepted June 5 2021, Published July 152021

Copyright: (c) 2021 The Author(s). Published by Palacký University Olomouc. This is an open access article distributed under the terms of the Creative Commons Attribution License (https://creativecommons.org/licenses/by/4.0/), which permits unrestricted use, distribution, and reproduction in any medium, provided the original author and source are credited. This license does not cover any third-party material that may appear with permission in the article. 
On the other hand, from this macro Theory of Selfdetermination, it is said of the basic psychological needs: autonomy, social relationships and competence. People seek to meet these needs when they perform an activity and their level of motivation is higher when they do (Ryan \& Deci, 2000). Satisfaction of the basic psychological needs of students will avoid boredom and will cause them to want to do physical activities in the future (Carrasco et al., 2015). Previous research has analyzed the improvements at the level of theoretical knowledge as a greater satisfaction of basic psychological needs in the exercise and motivation of groups organized in interactive groups versus traditional classroom organizations (Olaya Cuartero et al., 2020).

To this end, active methodologies have appeared in which they focus their importance of the teaching-learning process in students and not only on the result. Active methodologies are defined as those methods, techniques and strategies used by the teacher to convert the teaching process into activities that encourage active student participation and lead to learning (Puga \& Jaramillo, 2015). In line with this, research has been conducted using the active methodology Flipped Classroom or Flipped Learning (FL) in all areas of the Primary, Secondary and Higher Education curriculum (Campos-Gutiérrez et al., 2021; Fernández-Río et al., 2020; Ferriz-Valero et al., 2017; Hinojo Lucena et al., 2019; Østerlie \& Kjelaas, 2019). These authors studied the effects of the use of FL in the classroom on motivation, autonomy, motor commitment time, academic performance, etc. FL is a novel technique that appeared in the teaching-learning modalities thanks to the studies carried out by Bergmann and Sams (2012), who adopted this new educational model. They recorded videos of their classes for the students to watch at home before the class. In this way, in the classroom, they carried out activities related to these contents and solve doubts. According to these authors (Bergmann \& Sams, 2012), the Flipped Classroom has transformed teaching practice and this radical change allows to take on different roles with the students, however, this pedagogical approach has scarcely been examined in PE (Sargent \& Casey, 2020).

Using this technique, students come to class with the knowledge acquired and in the classroom, they are reinforced without the need to teach the theory again. This allows more time to be spent on the practical part of the session (García-Barrera, 2013). For this technique to work, students must watch the videos at home and acquire those contents, if not, they will not be able to follow the classes and it will be of no use (Bergmann \& Sams, 2014). For this reason, Killian et al. (2016) have reported that flipping content in university PE classes affords positive outcomes because it expands time spent on practical activities and extends feedback from instructors.

"A good way to take advantage of Information and Communications Technology is undoubtedly the flipped classroom. Those activities related mainly to the presentation and explanations of content are offered outside the classroom, using technological tools" (García-Barrera, 2013 , p. 2). This new technique is directly associated with the use of Information and Communications Technology and together they can be very useful in the teaching-learning process of students (González Fernández \& Carrillo Jácome, 2016). The conceptual contents that are worked on in the PE classroom also influence the motivation of the students (Goudas \& Biddle, 1994). To avoid a sedentary lifestyle and promote the practice of physical activity, it is necessary to propose striking activities such as Parkour. Parkour is defined as an activity where all kinds of urban architecture are used to follow your own path by overcoming the obstacles that come to your destiny (Suárez \& Fernández-Río, 2012). Introducing this activity generates an interest in the students since they see it as a way to have fun while practicing physical exercise (Álvarez \& Fernández-Río, 2012).

Taking into account that the content of parkour is considered novel and for practical learning, prior learning about safety aspects, basic movements and techniques are necessary (Suárez \& Fernández-Río, 2012), this content is compatible with the application of the Flipped Learning model, since the student does not have any prior knowledge previously acquired.

For all of the above, the present study aims to analyze the effect on student motivation after an intervention with the Flipped Learning teaching technique, using a Parkour Didactic Unit in primary school students.

\section{Methods}

\section{Experimental design}

This study was carried out through the implementation of a sequential exploratory mixed methods approach. In this way, the qualitative component precedes the quantitative element (Tashakkori \& Teddlie, 2003).

\section{Participants}

One hundred students of 6th grade of Primary (11-12 years old) participated in this study, of which, 45 were girls and 55 were boys (Table 1 ). The sample of this research was carried out in a subsidized educational center in the city of Alcoy, Spain. In general terms, the school is located in the central area of the city and the socioeconomic level of the students' families is medium-high.

\section{Ethics}

The research was approved both by the Ethics Committee of the University of Alicante, as well as by the management team of the educational center and the families involved.

Table 1 Sampling details

\begin{tabular}{|c|c|c|c|c|}
\hline & \multicolumn{4}{|c|}{ Class } \\
\hline & $69 \mathrm{~A}$ & $6 \circ \mathrm{C}$ & $6 \div B$ & $69 D$ \\
\hline Methodology & FLIP & FLIP & TRAD & TRAD \\
\hline Female & 11 & 11 & 11 & 12 \\
\hline Male & 14 & 14 & 12 & 13 \\
\hline Excluded & 1 & 0 & 1 & 0 \\
\hline Total & 26 & 25 & 24 & 25 \\
\hline
\end{tabular}

Note. $\mathrm{FLIP}=$ Flipped Learning teaching; $\mathrm{TRAD}=$ traditional teaching 


\section{Procedure}

The center has four lines or groups per school year, for which the four classes of $6^{\text {th }}$ grade of Primary participated. It was randomly decided that $6^{\circ} \mathrm{B}$ and $6^{\circ} \mathrm{D}$ would follow the teaching styles that were already used in the center regularly (TRAD group) and, otherwise, the $6^{\circ} \mathrm{A}$ and $6^{\circ} \mathrm{C}$ groups used the Flipped Learning teaching technique by watching videos created by the principal investigator for the present investigation (FLIP group).

Two students from the total sample were excluded. The exclusion criteria for the study were: Not taking the pre-test or post-test, not attending $80 \%$ of the classes taught and, in the case of the FLIP group, not having watched $70 \%$ of the videos on the platform Edpuzzle, because without watching the videos the FLIP technique does no effect.

In the session previous to the beginning of the Parkour work unit, the students of the two groups were explained separately what was going to be done during the next sessions: the methodology to be used, the contents and what they had to do, depending on the group to which they belonged. In the FLIP group, the operation of the Edpuzzle platform was explained so that they became familiar with the tools they should use in the process. After that, all the students took the motivation pre-test Motivation Questionnaire in Physical Education (Leo et al., 2016) in PE for primary school students.

Both the FLIP group and the TRAD group carried out the same didactic Parkour work unit, only the conceptual contents of the sessions were taught in the TRAD group in the first 5-6 minutes of the session. On the other hand, in the FLIP group, the students had a few days to watch the videos corresponding to that session. These videos comprise between one and three minutes each, following the recommendations (Bergmann \& Sams, 2014).

The tablet facilitated the research carried out at work since they had this resource both in PE classes and at home to watch the proposed videos. For this reason, each student has a tablet (provided by the school) for scholarly use.

Some of the videos used were taken from the YouTube platform and some were created by the lead researcher on the PowToon platform. In some of the videos, the character of the teacher appears in the form of a drawing, and they are related to her voice. In the rest, tutorials of Parkour jumps and maneuvers prepared by external experts in the field have been used.

Each session is complemented by two or three videos, depending on the concepts taught in that session. In total, nine explanatory videos were produced. In all the videos the students must answer between two and eight questions, depending on the video, related to the conceptual contents that appear. Some of these questions are multiple-choice questions and others are for the students to write their answers briefly.

The FLIP group had to view the videos throughout the Parkour didactic work unit. Access to the Edpuzzle platform was very simple (Figure 1), they only had to enter a password provided by the teachers and they accessed the class where all the videos were located.

Figure 1 Interface of the Edpuzzle technological tool used for the FLIP group
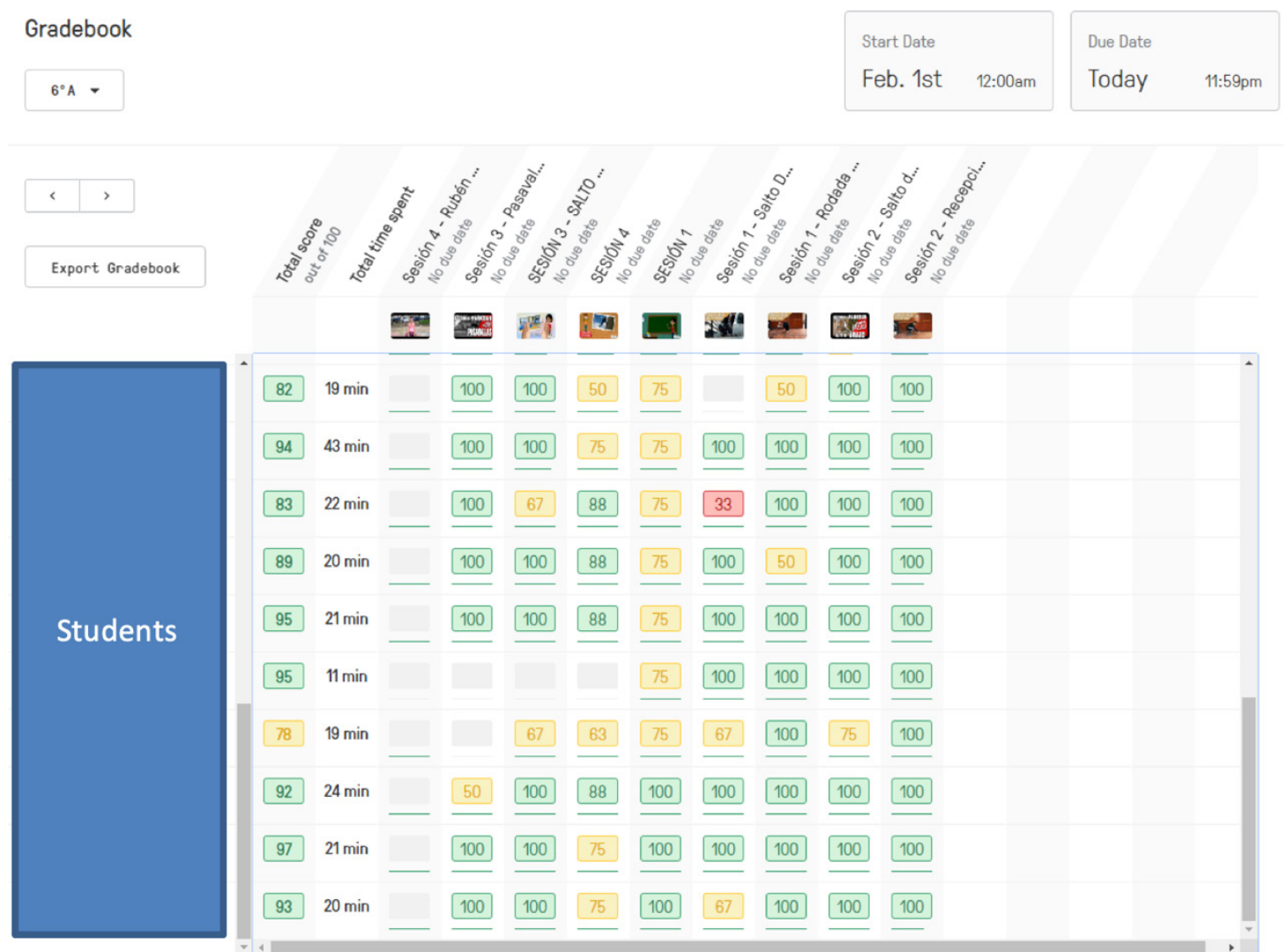
The teacher (main researcher) explained the conceptual contents to the students who did not watch the videos at home so that they could follow the classes normally. This type of case occurred only twice during the investigation.

The didactic work unit consisted of four sessions that began in the third week of February and ended the first week of March in all groups (before the COVID19 pandemic). In the first session, an introduction was made to the activity that was going to work, Parkour, and the precision jump and flip, which were the initial techniques, were explained.

In the second session, the receptions and the arm jump were worked. In the third session, more techniques of this sport were explained such as the free arm jump with a jump and $180^{\circ}$ turn and the hurdle pass. Finally, in the last session, a global review of Parkour and all the techniques worked was carried out. All these conceptual contents were put into practice in each of the sessions using posts with different levels of difficulty to practice the techniques and movements learned characteristic of this sport.

When the didactic unit of Parkour work ended, the students took, again, the motivation post-test Motivation Questionnaire in Physical Education (Leo et al., 2016).

Finally, the teachers conducted interviews with the students. The interviews were conducted in a room in the gym of the school during school hours during the last session of the Didactic Units. Since each interview lasted approximately 4 minutes and the session has 50 minutes, 10 students from each group-class were randomly interviewed. The students went one by one to the room, the students alternated to obtain the same number of interviews with gender male and female. The interviews were recorded with a tape recorder by the teacher for later transcription and in-depth study, with the voluntary consent of the school center and all the students and their legal representatives who participated in this study.

\section{Instruments}

Motivation Questionnaire in Physical Education in primary education has been validated (Leo et al., 2016) in the Spanish context for primary school children and composed of 18 different items that quantify intrinsic motivation, identified motivation, introjected motivation, external motivation and amotivation of the students. The students took a pre-test before starting the Parkour Didactic Unit and a post-test when they finished it.

\section{Personal interview}

Individual interviews were conducted with the students. In total, 40 interviews were randomly applied to students from the FLIP and TRAD groups, and they were semi-structured interviews (Díaz-Bravo et al., 2013), that is, an interview script was available for the participants to answer with total flexibility, adapting to the interviewees to express their points of view openly unlike a standardized interview. The interview questions for the FLIP and TRAD student had the same objectives, to discover the opinion of the students and their motivation regarding the two methodologies used in the PE class (Table 2). This process was carried out at the end of the Parkour didactic work unit, as a reflection of the methodology used with the students and to collect all possible data. The data analysis was collected through 40 interviews divided into 20 interviews with students using TRAD methodology and 20 interviews with students using FLIP methodology.

The interview questions are detailed in Table 2, based on sociodemographic data and questions about methodology, if they liked it or found it fun if they prefer to watch videos at home or in class, if it influences their motivation and why. The open-ended answers were transcribed and coded into five groups of opinion regarding the methodology and the effect of its use in the PE class. These codes were Novel, Fun, Useful Time, Accepted and Motivating.

Table 2 Semi-openstructure of the interviews

\begin{tabular}{|c|c|c|}
\hline $\begin{array}{l}\text { Question } \\
\text { number }\end{array}$ & FLIP students & TRAD students \\
\hline 1. & What is your name? & What is your name? \\
\hline 2. & What school do you go to? & What school do you go to? \\
\hline 3. & What class are you going to? & What class are you going to? \\
\hline 4. & $\begin{array}{l}\text { What methodology have you used in this unit, traditional or with } \\
\text { visualization of videos at home? }\end{array}$ & $\begin{array}{l}\text { What methodology have you used in this unit, traditional or with } \\
\text { visualization of videos at home? }\end{array}$ \\
\hline 5. & Do you like the Parkour unit? & Do you like the Parkour unit? \\
\hline 6. & What do you think about it? & What do you think about it? \\
\hline 7. & Have you had fun? Why? & Have you had fun? Why? \\
\hline 8. & Did you like to see theory contents at home? & Did you like to see theory contents in class? \\
\hline 9. & What do you think of that? & What do you think of that? \\
\hline 10. & $\begin{array}{l}\text { Do you think that the classes are more fluid and faster if the students watch } \\
\text { the videos of the theory at home? }\end{array}$ & Do you think that we waste a lot of time explaining theory in class? \\
\hline 11. & $\begin{array}{l}\text { Do you prefer to learn the theory at home through videos or have the } \\
\text { teacher explain it in class? }\end{array}$ & $\begin{array}{l}\text { Do you prefer to learn theory at home through videos made by the teacher } \\
\text { or explained by the teacher in class? }\end{array}$ \\
\hline 12. & $\begin{array}{l}\text { Do you think that by watching theory videos at home we have more time to } \\
\text { play and practice in class? }\end{array}$ & $\begin{array}{l}\text { Do you think that by watching the theory videos at home we have more time } \\
\text { to play and practice in class? Why? }\end{array}$ \\
\hline 13. & $\begin{array}{l}\text { Watching the videos at home, do you come to class motivated and eager? } \\
\text { Why? }\end{array}$ & Do you like it when we explain the theory in class? Or do you get/feel bored? \\
\hline 14. & Have you felt that with other units? & Do you feel motivated and eager when we do explanations in class? Why? \\
\hline
\end{tabular}




\section{Statistical analysis}

All quantitative continuous variables in the data set were subjected to a normality test (Shapiro-Wilk for $N>50$ or Kolmogorov-Smirnov). Moreover, the Mann-Whitney $U$ test was applied to analyze the differences between groups in terms of attendance and motivation. The quantitative data were subjected to a univariate statistical analysis for non-parametric samples, specifically, the Wilcoxon test was used to observe intra-group differences (pre vs. post). The effect size was also calculated using the software Microsoft Excel (Dominguez-Lara, 2018) according to the following formula $r=Z / \sqrt{ } N$, which provided an insight into the magnitude of the differences found, as the influence of the sample size was eliminated. The magnitude would be small (0.1-0.3), medium (0.3-0.5) and large (> 0.5; Cohen, 1988). Finally, a $95 \%$ confidence interval was calculated for the differences. The information collected by interviewers were transcribed and categorized by the main researcher. The analyses consisted of descriptive contingency tables by comparing the control and experimental groups (in the common questions), and by focusing only on the most frequent or interesting open answers (Cabrera, 2009). IBM SPSS Statistics (Version 24.0; IBM, Armonk, NY, USA) and Microsoft Excel (Version 2016; Microsoft, Redmond, WA, USA) were used. The level of significance was established at $p<.05$ in all cases.

\section{Results}

Sample equivalence

Firstly, a Mann-Whitney $U$ test found no significant differences between the groups in terms of attendance $(Z=-0.340$, $p=.827)$ and motivation $(Z=-0.270, p=.308)$.

\section{Motivation Questionnaire in Physical Education}

As can be seen in Table 3, in the FLIP group there are significant changes in all its variables. An increase in intrinsic motivation, identified motivation and introjected motivation is observed. On the other hand, the external motivation, as well as the amotivation of the students, has decreased after the intervention. Regarding the TRAD group, a significant decrease in intrinsic motivation and identified motivation was observed.

Second, results have been obtained according to the gender of the students. As can be seen in Table 4, in the FLIP group, boys significantly increased their intrinsic motivation, their identified regulation and their introjected motivation. Instead, their amotivation values decreased. In girls, only introjected motivation and external motivation increased $(p<.001$ and $p=.032$, respectively). In the TRAD group, no changes were observed, except for intrinsic motivation and identified motivation, which levels decrease significantly in both boys and girls.

\section{Interviews}

About the qualitative results that have been obtained through interviews with the students, they are collected in Tables 5 and 6. In the FLIP group, all students interviewed indicated that the use of this teaching technique makes it possible to use time effectively. More than $90 \%$ stated that this technique is fun and, they showed acceptance for implementing it on a day-to-day basis. Concerning the motivation, supporting the results shown in the previous paragraph (quantitative), $87.5 \%$ of the student indicated that they feel motivated, for example, watching the videos. However, despite indicating the novelty of this technique,

Table 3 Results obtained from the changes in motivation in students

\begin{tabular}{|c|c|c|c|c|c|c|c|c|}
\hline & \multicolumn{4}{|c|}{ FLIP } & \multicolumn{4}{|c|}{ TRAD } \\
\hline & Mean pre-test & Mean post-test & $Z$ & $p$ & Mean pre-test & Mean post-test & $Z$ & $p$ \\
\hline Intrinsic & 17.72 & 19.22 & 3.484 & $<.001$ & 18.12 & 16.62 & -4.322 & $<.001$ \\
\hline Extrinsic identified & 17.14 & 18.84 & 4.234 & $<.001$ & 16.97 & 16.20 & -3.598 & $<.001$ \\
\hline Extrinsic introjected & 13.84 & 17.48 & 5.670 & $<.001$ & 14.91 & 14.66 & -0.995 & .320 \\
\hline Extrinsic external & 13.52 & 12.50 & -2.157 & .031 & 12.70 & 12.58 & -0.693 & .489 \\
\hline Amotivation & 5.92 & 4.58 & -3.668 & $<.001$ & 6.60 & 6.35 & -0.825 & .409 \\
\hline
\end{tabular}

Table 4 Motivation results according to gender

\begin{tabular}{|c|c|c|c|c|c|c|c|c|}
\hline \multirow[b]{2}{*}{ Motivation } & \multicolumn{4}{|c|}{ Girls } & \multicolumn{4}{|c|}{ Boys } \\
\hline & Mean pre-test & Mean post-test & $z$ & $p$ & Mean pre-test & Mean post-test & $z$ & $p$ \\
\hline \multicolumn{9}{|l|}{ FLIP } \\
\hline Intrinsic & 18.59 & 18.64 & 0.130 & .897 & 17.04 & 19.68 & 3.947 & $<.001$ \\
\hline Extrinsic identified & 18.32 & 18.64 & 1.175 & .240 & 16.21 & 19.00 & 4.125 & $<.001$ \\
\hline Extrinsic introjected & 14.77 & 18.00 & 3.747 & $<.001$ & 13.11 & 17.07 & 4.289 & $<.001$ \\
\hline Extrinsic external & 13.82 & 11.77 & -2.150 & .032 & 13.29 & 13.07 & -0.910 & .363 \\
\hline Amotivation & 6.05 & 5.00 & -1.859 & .063 & 5.82 & 4.25 & -3.157 & .002 \\
\hline \multicolumn{9}{|l|}{ TRAD } \\
\hline Intrinsic & 18.09 & 16.43 & -3.049 & .002 & 18.16 & 16.80 & -3.163 & .002 \\
\hline Extrinsic identified & 16.35 & 15.65 & -2.578 & .010 & 17.56 & 16.72 & -2.536 & .011 \\
\hline Extrinsic introjected & 13.43 & 13.22 & -0.387 & .699 & 16.28 & 16.00 & -1.136 & .256 \\
\hline Extrinsic external & 11.65 & 11.65 & -0.074 & .941 & 13.68 & 13.44 & -0.955 & .339 \\
\hline Amotivation & 6.30 & 6.26 & -0.199 & .842 & 6.88 & 6.44 & -1.200 & .230 \\
\hline
\end{tabular}


less than $50 \%$ made any comments on this characteristic. Some examples are shown in Table 5.

As regards the control group, no student commented on the novelty aspect. On the other hand, more than $90 \%$ of the student stated some aspect of the fun and useful time of the sessions. Between $80 \%$ and $90 \%$ do not accept traditional teaching techniques, especially theory classes because they are boring and feels unmotivated in classes because they are long without doing anything or have assumed that they have to do so.

\section{Discussion}

The main objective of this research was to analyze the effects of the use of the Flipped Learning pedagogical approach on the motivation of students in PE classes.

Table 5 Results of the interviews with the FLIP students

\begin{tabular}{|c|c|c|}
\hline \multirow[b]{2}{*}{ Example } & \multicolumn{2}{|c|}{ Code } \\
\hline & FA & $\% \mathrm{FA}$ \\
\hline \multicolumn{3}{|l|}{ Novelty } \\
\hline $\begin{array}{l}\text { "We have never done this before and it's fun to try new things" (Student no. 21) } \\
\text { "An original way of learning" (Student no. 46) }\end{array}$ & 11 & 44 \\
\hline They do not refer to this aspect. & 13 & 56 \\
\hline \multicolumn{3}{|l|}{ Fun } \\
\hline $\begin{array}{l}\text { "Yes, I have had fun because it is an entertaining thing and how you have put the videos to us I liked it more than if they explained it to } \\
\text { us here" (Student no. 27) }\end{array}$ & 22 & 91.6 \\
\hline "I didn't like it at all" (Student no. 46) & 2 & 8.4 \\
\hline \multicolumn{3}{|l|}{ Useful time } \\
\hline $\begin{array}{l}\text { "Watching the video at home is as if you were teaching the class at school but at home and thus you don't waste time in class afterwards" } \\
\text { (Student no. 29) } \\
\text { "We don't waste so much time in class with explanations and if we see them at home, we skip those } 5 \text { minutes of explanation and use it } \\
\text { for something else" (Student no. 47) }\end{array}$ & 24 & 100 \\
\hline \multicolumn{3}{|l|}{ Accepted } \\
\hline $\begin{array}{l}\text { "I liked seeing the theory at home because here in class it gets more boring and we lose more time in physical education" (Student no. 45) } \\
\text { "I prefer to watch the theory at home with the videos because you save time and sometimes in class there are people who do not shut } \\
\text { up and do not listen to it well and at home it is better for me" (Student no. 49) }\end{array}$ & 22 & 91.6 \\
\hline $\begin{array}{l}\text { "On the one hand, well, I had something to do at home and on the other hand, not because I prefer someone to explain it to me" (Student } \\
\text { no. 48) }\end{array}$ & 2 & 8.4 \\
\hline \multicolumn{3}{|l|}{ Motivating } \\
\hline $\begin{array}{l}\text { "I see the video and I kind of want to do it" (Student no. 11) } \\
\text { "It encourages me more because I already know what we're going to do and it's cool" (Student no. 24) } \\
\text { "In class it's a theory roll and I think it's more fun at home" (Student no. 45) }\end{array}$ & 21 & 87.5 \\
\hline $\begin{array}{l}\text { "Well, not much because the videos don't motivate me much, I just learn" (Student no. 3) } \\
\text { "I come just as motivated or better according to the video" (Student no. 21) }\end{array}$ & 3 & 12.5 \\
\hline
\end{tabular}

Note. FA = frequency of code appearance.

Table 6 Results of the interviews with the TRAD students

\begin{tabular}{|c|c|c|}
\hline \multirow[b]{2}{*}{ Example } & \multicolumn{2}{|c|}{ Code } \\
\hline & FA & $\% \mathrm{FA}$ \\
\hline \multicolumn{3}{|l|}{ Novelty } \\
\hline They do not refer to this aspect. & 0 & 0 \\
\hline \multicolumn{3}{|l|}{ Fun } \\
\hline $\begin{array}{l}\text { "I found it more fun to practice it" (Student no. 63) } \\
\text { "I prefer the practical part because it is more fun (Student no. 77) }\end{array}$ & 14 & 93.3 \\
\hline “I didn't like it" (Student no. 91) & 1 & 6.7 \\
\hline \multicolumn{3}{|l|}{ Useful time } \\
\hline "As in class we lose much of what is necessary but maybe we could summarize it" (Student no. 87) & 14 & 93.3 \\
\hline "We lose a lot of time but it is necessary" (Student no. 88) & 1 & 6.7 \\
\hline \multicolumn{3}{|l|}{ Accepted } \\
\hline $\begin{array}{l}\text { "See it in class to ask" (Student no. 93) } \\
\text { "In class we learn more and we are with our friends" (Student no. 91) } \\
\text { "I prefer to see it in class in case you have any questions" (Student no. 88) }\end{array}$ & 3 & 20 \\
\hline "I did not like to see the theory in class because it is very boring" (Student no. 55) & 12 & 80 \\
\hline \multicolumn{3}{|l|}{ Motivating } \\
\hline "Yes, because I know that we are going to finish the theory and we are going to practice it later" (Student no. 83) & 2 & 13.4 \\
\hline $\begin{array}{l}\text { "I get bored because it is a long time stopped and in the end we end up talking" (Student no. 55) } \\
\text { "It's a bit boring but you have to know it" (Student no. 91) } \\
\text { "Normally I like it but there are times when I get bored" (Student no. 61) }\end{array}$ & 13 & 86.6 \\
\hline
\end{tabular}

Note. FA = frequency of code appearance. 
These results are supported by other research (Hinojo Lucena et al., 2020; Østerlie \& Kjelaas, 2019) as students are more motivated in PE classes when the FL methodology is applied. This could be due to the innovative nature of the content of the Parkour teaching unit (González-Cutre \& Sicilia, 2019). In line with this statement, the qualitative analysis of our study indicates that the theme and unit of parkour are more motivating and innovative than other sports in both methodologies ("This is the didactic unit in which I had the best time." Student no. 65, TRAD group; "Cool because I've never done parkour before. When you get to know a new thing, you like it more and you like it more." Students no. 50 and no. 43, FLIP group).

Besides, the quantitative results showed that the intrinsic motivation of the students has increased significantly in FLIP group, unlike other studies (Campos-Gutiérrez, 2021; Ferriz-Valero et al., 2017; Gómez-García et al., 2019).

This work unit is innovative in the educational center in which the present investigation has been developed since it had not been worked before in the center. In line with these first results regarding FLIP group, Alvárez and Fernández (2012) affirm that Parkour increases the motivation of students in the school environment since it is a new activity in which they promote their self-esteem because they must constantly improve themselves, which generates great interest and motivation in the students. Moreover, the results of the present study are supported by Olaya Cuartero et al. (2020), who showed greater satisfaction of basic psychological needs and intrinsic motivation of classroom organization in interactive groups as compared to TRAD.

It was also very attractive to the students as they practiced jumps and acrobatics, characteristic of Parkour. This aspect has also been reflected in the interviews with the students, where they stated that "they liked it and had fun working on Parkour in PE classes because it was something new". One example of this could be in code Novelty ("Usually we kids do football and stuff and this kind of stuff is really cool" Student no. 22, FLIP group).

Significant changes have been obtained in the variable amotivation of the students of the FLIP group. The students feel less lack of motivation in the PE classes, unlike the TRAD group who showed the same values as before carrying out the intervention. Amotivation constitutes the last block in the continuum of self-determination and is characterized by the fact that the student has no intention of carrying out an activity and, therefore, the behaviors have not been motivated either intrinsically or extrinsically (Sánchez-Oliva et al., 2012). Therefore, the results of this research coincide with other studies that observed a decrease in the amotivation variable (Fernández-Río et al., 2020).

In the third place, $86 \%$ of the interviewed students from the TRAD group share the feeling of boredom in the explanations of the PE class and, consequently, prefer a completely practical session such as the one carried out by the FLIP group. Also, all the students who experienced the flipped learning approach agree that time is used more than the feeling of wasting time that the TRAD group had (Motivation code: "It's a bit boring but it's worth knowing"
Student no. 90, TRAD group; Motivation code: “It's not super fun at the time" Student no. 92, TRAD group).

Although at the quantitative level there were no differences in companionship between the FLIP and TRAD groups, it is shown that the development of this didactic Parkour unit could be led to the development of values such as companionship since in most activities they had to work as a team and help each other to overcome obstacles and, in other activities, it was them those who had to overcome their fears and carry out the movements with autonomy. The Parkour didactic unit required constant teamwork and this aspect increases the motivation of the students in carrying out the activities (Navarro-Patón et al., 2017).

Referring to the limitations and future research, it may be possible that Parkour itself would have been interesting and motivating, therefore, further research is required to study the role of flipped learning in this context. In addition, it would be advisable to use in the future a validated type of instrument for the qualitative interview. For example, an instrument that measures and evaluates the motivational aspects in students after learning through several educational methodologies. In this sense, the coding, questions and answers will be more reliable.

\section{Conclusions}

This research shows different conclusions in relation to the motivation and practical application of the FL. Firstly, intrinsic motivation increased significantly in FL group, so it seems that the FLIP methodology increases its values, as are discussed in the previous section. Moreover, the qualitative results indicate greater motivation in the group that used the FL methodology. Secondly, the amotivation values decrease in the students who carried out the Parkour work unit through the FL approach. Finally, linking the theory to practical application. The FL approach allows using more time in PE classes and, consequently, it is perceived as more fun for the students.

\section{Conflict of interest}

The authors report no conflict of interest.

\section{References}

Alotaibi, T., Almuhanna, R., Alhassan, J., Alqadhib, E., Mortada, E., \& Alwhaibi, R. (2020). The relationship between technology use and physical activity among typically-developing children. Healthcare, 8(4), Article 488. https://doi.org/ $\underline{10.3390 / \text { healthcare8040488 }}$

Álvarez, C. S., \& Fernández-Río, J. (2012). El parkour en la escuela [Parkour at school]. Lulú.

Bergmann, J., \& Sams, A. (2012). Flip your classroom: Reach every student in every class every day. International Society for Technology in Education.

Bergmann, J., \& Sams, A. (2014). Dale la vuelta a tu clase [Flip your class]. Ediciones SM.

Cabrera, I. (2009). El análisis de contenido en la investigación educativa: propuesta de fases y procedimientos para la etapa de evaluación de la información [The content analysis in the educative research: Phase proposal and procedures for the information evaluation stage]. Revista Pedagogía Universitaria, 14(3), 71-93.

Campos-Gutiérrez, L. M., Sellés-Pérez, S., García-Jaén, M., \& Ferriz-Valero, A. (2021). Aula invertida en educación física: aprendizaje, motivación y tiempo de práctica motriz [Flipped learning in physical education: Learning, motivation and motor practice time]. Revista Internacional De Medicina Y Ciencias 
De La Actividad Física Y Del Deporte, 21(81), 63-68. https://doi.org/10.15366/ rimcafd2021.81.005

Carrasco, H., Ríos, L. J. C., Tamayo, I. M., Cajas, B., \& Garrido, R. E. R. (2015). Efectos de un programa extraescolar basado en juegos reducidos sobre la motivación y las necesidades psicológicas básicas en las clases de educación física [Effects of a small sided games extracurricular program on motivation and basic psychological needs in physical education classes]. Revista Iberoamericana de Psicología del ejercicio y el deporte, 10(1), 23-31. https://www.riped-online.com/ abstract/effects-of-a-small-sided-games-extracurricular-program-on-motivation-and-basicpsychological-needs-in-physical-education-19064.html

Castro, M. J., Pierón, M., \& González, M. A. (2006). Actitudes y motivación en educación física escolar [Attitudes and motivation in school physical education]. Retos, 10, 5-22. https://doi.org/10.47197/retos.v0i10.35059

Cohen, J. (1988). Statistical power analysis for the behavioral sciences (2nd ed.) Lawrence Erlbaum Associates. https://doi.org/10.4324/9780203771587

Díaz-Bravo, L., Torruco-García, U., Martínez-Hernández, M., \& Varela-Ruiz, M. (2013). La entrevista, recurso flexible y dinámico [The interview, a flexible and dynamic resource]. Investigación en Educación Médica, 2(7), 162-167. https:// doi.org/10.1016/s2007-5057(13)72706-6

Dominguez-Lara, S. (2018). Magnitud del efecto, una guía rápida [Effect size, a quick guide]. Educación médica, 19(4), 251-254. https://doi.org/10.1016/i. edumed.2017.07.002

Fernández-Río, J., de las Heras, E., González, T., Trillo, V., \& Palomares, J. (2020). Gamification and physical education. Viability and preliminary views from students and teachers. Physical Education and Sport Pedagogy, 25(5), 509-524. https://doi.org/10.1080/17408989.2020.1743253

Ferriz-Valero, A., Sebastià Amat, S., \& García Martínez, S. (2017). Clase invertida como elemento innovador en Educación Física: efectos sobre la motivación y la adquisición de aprendizajes en Primaria y Bachillerato [Inverted class as an innovative element in physical education: Effects on motivation and acquisition of learning in primary and high school]. In R. Roig-Vila (Ed.), Investigación en docencia universitaria. Diseñando el futuro a partir de la innovación educativa (pp. 200-215). Editorial Octaedro.

García-Barrera, A. (2013). El aula inversa: cambiando la respuesta a las necesidades de los estudiantes [The inverse classroom: Changing the response to student needs]. Avances en supervisión educativa, 19, 1-8. https://doi. org/10.23824/ase.v0i19.118

Giménez, A. M., Río, J. F., \& Estrada, J. A. C. (2013). Climas motivacionales, necesidades, motivación y resultados en Educación Física [Motivational climates, needs, motivation and outcomes in physical education]. Aula Abierta, 41(1), 63-72.

Gómez-García, J., Sellés, S., \& Ferriz-Valero, A. (2019). Flipped Classroom Como Propuesta en la Mejora del Rendimiento Académico y Motivación del Alumnado en Educación Física [Flipped classroom as a proposal to improve the academic performance and motivation of the pupil in physical education]. Kronos, 18(2), 1-12. https://revistakronos.info/articulo/flipped-classroom-como-propuesta-enla-mejora-del-rendimiento-academico-y-motivacion-del-alumnado-en-educacion-fisica2753-sa-i5e0a32d14a026

González Fernández, N., \& Carrillo Jácome, G. A. (2016). El Aprendizaje Cooperativo y la Flipped Classroom: una pareja ideal mediada por las TIC [Cooperative Learning and the Flipped Classroom: An ideal couple mediated by ICT]. Revista Digital de Comunicación, 5(2), 43-48.

González-Cutre, D., \& Sicilia, Á. (2019). The importance of novelty satisfaction for multiple positive outcomes in physical education. European Physical Education Review, 25(3), 859-875. https://doi.org/10.1177/1356336X18783980

Goudas, M., \& Biddle, S. (1994). Perceived motivational climate and intrinsic motivation in school physical education classes. European Journal of Psychology of Education, 9(3), 241-250. https://doi.org/10.1007/BF03172783

Gutiérrez, M., Pérez, L. M. R., \& López, E. (2011). Clima motivacional en educación física: Concordancia entre las percepciones de los alumnos y las de sus profesores [Motivational climate in physical education: Agreement between students' perceptions and those of their teachers]. Revista de Psicología del Deporte, 20(2), 321-335.

Hinojo-Lucena, F. J., Aznar-Díaz, I., Cáceres-Reche, M. P., \& Romero-Rodríguez, J. M. (2019). Opinión de futuros equipos docentes de educación primaria sobre la implementación del mobile learning en el aula [Opinion of future primary education teaching teams on the implementation of mobile learning in the classroom]. Revista Electrónica Educare, 23(3), 283-299. https://doi. org/10.15359/ree.23-3.14

Hinojo Lucena, F. J., Lopez Belmonte, J., Fuentes Cabrera, A., Trujillo Torres, J. M., \& Pozo Sánchez, S. (2020). Academic effects of the use of flipped learning in physical education. International Journal of Environmental Research and Public Health, 17(1), Article 276. https://doi.org/10.3390/iierph17010276

Killian, C. M., Trendowski, T. N., \& Woods, A. M. (2016, June 8-11). Students' perceptions of flipped instruction in a university physical activity course [Paper presentation]. 2016 AIESEP International Conference, Laramie, WY, USA.

Leo, F. M., García-Fernández, J. M., Sánchez-Oliva, D., Pulido, J. J., \& García- Calvo,

T. M. (2016). Validación del cuestionario de motivación en Educación Física en educación primaria (CMEF-EP) [Validation of the Motivation in Physical Education Questionnaire in Primary Education (CMEF-EP)]. Universitas Psychologica, 15(1), 315-326. https://doi.org/10.11144/Javeriana.upsy15-1.vmpe

Navarro-Patón, R., Basanta-Camiño, S., \& Abelairas-Gómez, C. (2017). Los juegos cooperativos: incidencia en la motivación, necesidades psicológicas básicas y disfrute en Educación Primaria [Cooperative games: Incidence in motivation, basic psychological needs and enjoyment in primary school]. Sportis, 3(3), 589-604. https://doi.org/10.17979/sportis.2017.3.3.2088

Ntoumanis, N. (2001). A self-determination approach to the understanding of motivation in physical education. British Journal of Educational Psychology, 71(2), 225-242. https://doi.org/10.1348/000709901158497.

Olaya Cuartero, J., García Jaén, M., García Martínez, S., \& Ferriz Valero, A. (2020). Los grupos interactivos en Educación Física: Una experiencia docente en Educación Secundaria [Interactive Groups in Physical Education: A teaching experience in Secondary Education]. Retos, 38, 369-374. https://doi.org/10.47197/retos. v38i38.74606

$\emptyset$ sterlie, O., \& Kjelaas, I. (2019). The perception of adolescents' encounter with a Flipped Learning intervention in Norwegian Physical Education. Frontiers in Education, 4, Article 114. https://doi.org/10.3389/feduc.2019.00114

Portman, P. A. (1995). Who is having fun in physical education classes? Experiences of sixth-grade students in elementary and middle schools. Journa of Teaching in Physical Education, 14(4), 445-453. https://doi.org/10.1123/ itpe.14.4.445

Puga, L. A., \& Jaramillo, L. M. (2015). Metodología activa en la construcción del conocimiento matemático [Active methodology in the construction of mathematical knowledge]. Sophia, 19, 291-314.

Ryan, R. M., \& Deci, E. L. (2000). Self-determination theory and the facilitation of intrinsic motivation, social development, and well-being. American Psychologist, 55(1), 68-78. https://doi.org/10.1037/0003-066X.55.1.68

Ryan, R. M., \& Deci, E. L. (2017). Self-determination theory: Basic psychological needs in motivation, development, and wellness. The Guilford Press. https://doi. org/10.1521/978.14625/28806

Ryan, R. M., \& Deci, E. L. (2020). Intrinsic and extrinsic motivation from a selfdetermination theory perspective: Definitions, theory, practices, and future directions. Contemporary Education Psychology, 61, Article 101860. https://doi. org/10.1016/i.cedpsych.2020.101860

Sánchez-Oliva, D., Marcos, F. M. L., Amado, D., Alonso, I. G. P., \& García-Calvo, T. (2012). Desarrollo de un cuestionario para valorar la motivación en educación física [Develop of a questionnaire to assess the motivation in physical education]. Revista Iberoamericana de Psicología del Ejercicio y el Deporte, 7(2), 227-250. https://www.riped-online.com/abstract/develop-of-a-questionnaire-to-assessthe-motivation-in-physical-education-18986.html

Sanmartín, M. G. (2014). Relaciones entre el clima motivacional, las experiencias en educación física y la motivación intrínseca de los alumnos [Relationships among motivational climate, physical education experiences and pupils' intrinsic motivation]. Retos, 26, 9-14. https:/doi.org/10.47197/retos.v0i26.34387

Sargent, J., \& Casey, A. (2020). Flipped learning, pedagogy and digital technology: Establishing consistent practice to optimise lesson time. European Physical Education Review, 26(1), 70-84. https://doi.org/10.1177/1356336X19826603

Smith, A., \& Parr, M. (2007). Young people's views on the nature and purposes of physical education: A sociological analysis. Sport, Education and Society, 12(1), 37-58. https://doi.org/10.1080/13573320601081526

Suárez, C., \& Fernández-Río, J. (2012). El Parkour en la escuela [Parkour at school]. Lulu.

Tashakkori, A., \& Teddlie, C. (Eds.). (2003). Handbook of mixed methods in social \& behavioral research. Sage. 